\title{
Editorial to the Special Issue:
}

The Cultural Bias of Religiosity: Concepts, Measurements, and Results from Non-Western Perspectives

\author{
Sarah Demmrich \\ Cluster of Excellence "Religion and Politics", chair of sociology of religion, \\ University of Münster, Münster, Germany \\ kabogan@uni-muenster.de \\ Ulrich Riegel \\ Faculty I: Department of Catholic Theology, University of Siegen, \\ Siegen, Germany \\ ulrich.riegel@uni-siegen.de
}

The concept of religiosity as a highly individual aspect of religion and its research was shaped in Protestant circles in the Western context (Belzen, 2015; Demmrich, Allolio-Näcke \& Wolfradt, in press), and has inspired a huge body of research and further developments in empirical theology, as well as in the social sciences, focusing on religiosity. However, resulting biases of individualisation and a strongly self-centred perspective of the concept of contemporary religiosity have proved to be a pitfall regarding accurate descriptions, measurements, and the accompanying empirical findings on religiosity internationally.

On one hand, this observation raises the question of whether research on religiosity is a science of Western Christianity (Cutting \& Walsh, 2008; Hill \& Hood, 1999; Loewenthal, 2000); on the other hand, it brings to the fore indigenous approaches to theory and method from non-individualised contexts (e.g. the concepts of Muslim or Jewish religiosity - see Dover, Miner \& Dowson, 2007; Ghorbani, Watson, Sarmast \& Chen, 2018). Such approaches, of religionand culture-sensitive concepts and measures for different contexts, have been developed during the last few years (e.g. Abu-Raiya \& Pargament, 2011; Ağllkaya-Şahin, 2015; Demmrich, 2020; Kamble, Watson, Marigoudar \& Chen, 2014; Ok, 2016). These not only allow a more differentiated description of such religiosities, but also facilitate a valid research into its correlates. However, so far there are only a few of these alternative measures of non-individualised religiosity; more instruments appropriate to various cultural contexts are needed (Hill \& Edwards, 2013). 
Moreover, even within the Western context, contemporary concepts and instruments are only partially applicable to the adequate measurement of religiosity in highly religious individuals. For example, an orthodox belief practised in some Protestant Free Churches is often not contradicted by life in a modern society (Vermeer \& Scheepers, 2017). Such empirical results raise the question of whether contemporary conceptualisations of religiosity and their operationalisation are too strongly oriented towards the ideal of an enlightened and individualised belief. Consequently, a new understanding of highly religious milieus - which are growing in modern societies, as countermovements against secularity — are stimulating a new concept of religiosity beyond individualised belief (e.g. Fresh Expressions, megachurches, religious fundamentalism; see Herriot, 2009).

In light of these two frontiers, we invited to the international conference 'Religiosity in East and West: Conceptual and Methodological Challenges' at the University of Munster, Germany, from 25 to 27 June 2019. Over these three days, four invited keynote speakers and more than 50 successful applicants from 17 countries - ranging from America and Europe to the Middle East and the Far East - discussed established concepts of religiosity. In plenary meetings and in smaller collegial sessions, they aimed to expand these concepts using alternative concepts where appropriate. With its conference proceedings, and scholars from diverse religious and cultural contexts, this interdisciplinary scientific forum targeted the stimulation of international and intercultural scientific discourse and the inducement of further conceptual developments in this kind of research.

In this special issue of the Journal of Empirical Theology, titled 'The Cultural Bias of Religiosity: Concepts, Measurements, and Results from Non-Western Perspectives', we pay special attention to those contributions to the conference that are either qualitatively or quantitatively researching religiosity from such perspectives, or laying the foundation for such studies. ${ }^{1}$

As a foundational contribution, Zuhal Ağılkaya-Şahin (Istanbul Medeniyet University, Turkey) serves up as a prelude an article based on her conference keynote, in which she presents a critical analysis of measurements of Islamic-Turkish religiosity. Embedding her reasoning in a historical account of Turkey as a Muslim-majority country with a long history of the

1 Three additional conference proceedings are in press: a special issue of the Archive for the Psychology of Religion (Sage), with a focus on psychological contributions; an edited volume with the publisher Springer in the series Sociology of Religion, which targets sociological conference contributions; and an edited volume with the publisher Waxmann in the series Research on Religious and Spiritual Education, concentrating on theological contributions and those from religious education. 
social-scientific study of religion, she introduces us to early, adapted and authentic scales of this context, and outlines specific issues intrinsic not only to these measurements, but also to Turkish Muslims. Ağılkaya-Şahin concludes with the prospect of the further necessity for research into methods of a high scientific standard, as well as pointing out the rapid religious change in Turkish society, and the accompanying need to adapt the scales appropriately.

The second article, on Jewish religiosity - which also originates from a keynote-is presented by Aryeh Lazar (Ariel University, Israel). Starting with the distinction between orthodoxic and orthopractic religions, Lazar uses Israel as a case study to prove that Western concepts and measurements of religiosity fail to draw the correct picture of an orthopractic background in this cultural environment. Lazar suggests taking seriously the various groups in orthopractic societies that represent different ways of dealing with prescribed religious practices, and primarily assessing in-group differences.

Going deeper into empirical studies on religiosity beyond the Western-Christian context, three contributions use comparative studies as a means of identifying commonalities and specificities of religiosity and its correlates. First, Kenan Sevinç (Çanakkale University, Turkey) analyses crosscultural attitudes towards abortion, homosexuality and the use of contraception, on a quantitative basis. Using data from the Global Attitudes Project, Sevinç shows that non-religious individuals living in the Far East perceive abortion, contraceptive use and homosexuality to be less morally acceptable than Western Europeans do. However, there is also great variance within the non-religious, in both the Far East and the West.

Second, Meike Haken (Technical University of Berlin, Germany) offers an ethnographic article; a cross-cultural analysis of religious festivals. On the basis of the concept of celebration, and relying on videographically generated data from Christian events in Europe as well as web-based data from the Hindu Kumbh Mela in India, she demonstrates the transferability of theories in the context of a comparison of religions. Haken identifies a stable dimension of religious celebration, despite the fact that her material is taken from both an individualised Western environment and a non-individualised Eastern environment.

Third, Ramona Bullik, Sakin Özışık and Anika Steppacher (Bielefeld University, Germany) show us how individuals from different cultural backgrounds perceive their own religious or non-religious biographies in the context of migration, i.e. after leaving the environment that has most deeply influenced their religious socialisation. In contrast to well-established but often criticised theories of religious development (e.g. Fowler, 1981), the authors conclude (from a comparison between two selected cases from a bigger 
interview study) that religious development is not a linear, upward process. Moreover, their Religious-Style Interview method (Streib \& Keller, 2018) seems to be cross-culturally applicable.

The final contribution to our special issue is from Hande Gür (Middle Eastern Technical University, Turkey), and targets the highly topical scientific debate around 'spiritual but not religious' (SBNR), with an ethnographic study on individuals from Turkey. Her in-depth research on converts to a contemporary Islamic-Mystic movement is nested in a historical analysis of the changing relationship between such movements and the Ottoman Empire, and later the Turkish state. With this indigenous approach, Gür shows us how among these spiritual seekers, the self-attribution of SBNR is shaped in a different manner compared to the Western-Christian context. While they identify with a contemporary form of the traditional Sufi order, they regard themselves as religious but 'not that kind of religious', as they distance themselves from orthodox mainstream Islam and its politicisation in Turkey. With these findings, Gür uncovers central aspects of the limited applicability of the Western definition of spirituality and its relation to religiosity.

\section{References}

Abu-Raiya, H. \& Pargament, K. I. (2011). Empirically based psychology of Islam. Mental Health, Religion \& Culture, 14, 93-115. doi: 10.1080/13674670903426482.

Ağılkaya-Şahin, Z. (2015). The problem of appropriate psychology of religion measures for non-Western Christian samples with respect to the Turkish-Islamic religious landscape. In Z. Ağılkaya-Şahin, H. Streib \& R. W. Hood (Eds.), Psychology of Religion in Turkey (S. 65-105). Leiden: Brill. doi: 10.1163/978900429o884_oo5.

Belzen, J. A. v. (2015). Religionspsychologie: Eine historische Analyse im Spiegel der Internationalen Gesellschaft [The psychology of religion: A historical analysis as a reflection of the International Association]. Berlin: Springer.

Cutting, M. \& Walsh, M. (2008). Religiosity scales: What are we measuring in whom? Archive for the Psychology of Religion, 30, 137-153. doi: 10.1163/157361208X317006.

Demmrich, S. (2020). How to measure Baha'i religiosity: The CRSi-2o for Baha'is as a first reliable and valid measurement. Religions, 11, 29. doi: 10.339o/rel11010029.

Demmrich, S., Allolio-Näcke, L. \& Wolfradt, U. (in press). The psychology of religion in Germany up to 2020. In K. L. Ladd, J. Basu, V. DeMarinis, Ü. Ok \& W. Zangari (Eds.), Cambridge International Handbook of the Psychology of Religion. Cambridge: Cambridge University Press.

Dover, H., Miner, M. \& Dowson, M. (2007). The nature and structure of Muslim religious reflection. Journal of Muslim Mental Health, 2, 189-210. doi: 10.108 o/15564900701614858. 
Fowler, J. W. (1981). Stages of Faith. San Francisco: Harper \& Row.

Ghorbani, N., Watson, P. J., Sarmast, Z. \& Chen, Z. J. (2018). Post-critical beliefs and religious reflection: Religious openness hypothesis in Iranian university and Islamic seminary students. Journal of Empirical Theology, 37, 49-70. doi: 10.1163/15709256-12341367.

Herriot, P. (2009). Religious Fundamentalism: Global, Local and Personal. London: Routledge.

Hill, P. C. \& Edwards, E. (2013). Measurement in the psychology of religiousness and spirituality: Existing measures and new frontiers. In K. I. Pargament, J. J. Exline \& J. W. Jones (Eds.), APA Handbook of Psychology, Religion, and Spirituality (Vol. 1): Context, Theory, and Research (p. 51-77). American Psychological Association.

Hill, P. C. \& Hood, R. W. (1999). A preliminary note on measurements and scales in the psychology of religion. In P. C. Hill \& R. W. Hood (Eds.), Measures of Religiosity (pp. 3-8). Birmingham: Religious Education Press.

Kamble, S. V., Watson, P. J., Marigoudar, S. \& Chen, Z. (2014). Varieties of openness and religious commitment in India. Archive for the Psychology of Religion, 36, 172-198. doi: $10.1163 / 15736121-12341283$.

Loewenthal, K. M. (2000). The Psychology of Religion. Oxford: One World.

Ok, Ü. (2016). The Ok-Religious Attitude Scale (Islam). Journal of Beliefs \& Values, 37 , 55-67. doi: 10.108 o/13617672.2016.1141529.

Streib, H. \& Keller, B. (2018). Manual for the assessment of religious styles in faith development interviews (of the Manual for Faith Development Research). Retrieved from https://pub.uni-bielefeld.de/download/2920987/2932661/Streib_Keller_ Manual\%2ofor\%2othe\%2oAssessment.pdf [04/06/2020].

Vermeer, P. \& Scheepers, P. (2017). Comparing political attitudes of Evangelicals with the attitudes of mainline Christians and non-church members in the Netherlands. Politics and Religion, 11, 116-145. doi: 10.1017/S1755048317000566. 